\title{
The Advance of Woody and Shrub Vegetation \\ to the Mountains and Changes in the Composition of Tundra Communities (Poperechnaya Mountain, the Zigalga Mountain Range in the Southern Urals)
}

\author{
Andrei A. Grigor'ev*a,c, \\ Olga V. Erokhina ${ }^{a}$, Svetlana U. Sokovnina ${ }^{a}$, \\ Yulia V. Shalaumova ${ }^{\mathrm{b}, \mathrm{c}}$ and Dmitryi S. Balakin \\ ${ }^{a}$ Institute of Plant and Animal Ecology UB RAS \\ 202, 8 Marta Str., Ekaterinburg, 620144, Russia \\ ${ }^{b}$ Institute of Industrial Ecology UB RAS \\ 20 S. Kovalevskoj Str., Ekaterinburg, 620990, Russia \\ ${ }^{c}$ Ural State Forest Engineering University \\ 37 Sibirsky trakt, Ekaterinburg, 620100, Russia
}

Received 27.04.2018, received in revised form 16.06.2017, accepted 22.07.2018

Estimation of the dynamics of zonal and mountain tundra plant communities is extremely relevant in modern conditions of climate change. This article demonstrates the results of the estimation of woody and shrub vegetation progression to higher mountains at the Zigalga mountain range (the Southern Urals) using various methods: the comparison of aerial and satellite images, the repeated landscape photographs made at different times and also the examination of Juniperus sibirica Burgsd. age structure at different altitudes. The upward shift of woody and shrub vegetation is caused by the air temperature rise and increased precipitation during the winter periods in the Southern Urals. Vertical and horizontal upper limit shifts of open woodland from 1958 to 2012 are demonstrated. The vertical shift was determined to be $0.74 \mathrm{~m} /$ year and the horizontal one is $0.20 \mathrm{~m} /$ year. Based on the study of $J$. sibirica age structure, the fact of its advancement to the mountains during the last two centuries has been established. The research has been focused on the floristic composition of the mountain tundra communities with different J. sibirica cover. The floristic composition of the mountain tundra communities demonstrates their typological similarity. Introduction of J. sibirica leads to structural reorganization. The observed trends for vascular plants do not have any correlation with the height above sea level. Species composition of lichen synusia does not depend on J. sibirica cover, but it correlates with the altitude. Species richness and abundance of terrestrial lichens decrease in plant communities located lower on the mountain slope.

(C) Siberian Federal University. All rights reserved

This work is licensed under a Creative Commons Attribution-NonCommercial 4.0 International License (CC BY-NC 4.0).

* Corresponding author E-mail address: grigoriev.a.a@ipae.uran.ru 
Keywords: aerial and satellite images, landscape photographs, upper limit of woody and shrub vegetation, open spruce woodland, Juniperus sibirica Burgsd., mountain tundra plant communities, climate change, the Southern Urals.

Citation: Grigor'ev A.A., Erokhina O.V., Sokovnina S.U., Shalaumova Yu.V., Balakin D.S. The advance of woody and shrub vegetation to the mountains and changes in the composition of tundra communities (Poperechnaya mountain, the Zigalga mountain range in the Southern Urals). J. Sib. Fed. Univ. Biol., 2018, 11(3), 218-236. DOI: 10.17516/1997-1389-0067.

\title{
Продвижение древесно-кустарниковой растительности в горы и изменение состава тундровых сообществ (хр. Зигальга, Южный Урал)
}

\author{
А.А. Григорьев ${ }^{a}$, О.В. Ерохина ${ }^{a}$, \\ С.Ю. Соковнина ${ }^{a}$, Ю.В. Шалаумова ${ }^{6}$, Д.С. Балакин ${ }^{\text {}}$ \\ aинтитут экологии растений и животных УрО РАН \\ Россия, 620144, Екатеринбург, ул. 8 Марта, 202 \\ ${ }^{6}$ Институт промышленной экологии УрО РАН \\ Россия, 620990, Екатеринбург, ул. С. Ковалевской, 20 \\ ${ }^{8}$ Уральский государственный лесотехнический университет \\ Россия, 620100, Екатеринбург, Сибирский тракт, 37
}

Выявление особенностей динамики растительных сообществ горных и зональных тундр крайне актуально в современных условиях климатических изменений. Нами проведена оценка продвижения древесно-кустарниковой растительности выше в горы на Южном Урале на хр. Зигальга с помощью комплекса методов: сравнения разновременных аэрофото- и спутниковых изображений, повторных ландшафтных фотоснимков и изучения возрастной структуры можжевельника сибирского (Juniperus sibirica Burgsd.) на различных высотах над ур. м. Продвижению древесно-кустарниковой растительности на Южном Урале благоприятствовало повышение температуры и количества осадков в зимнее время. Показаны вертикальные и горизонтальные сдвиги верхней сплошной гранищы редколесий за период с 1958 по 2012 г. Вертикальный сдвиг сплошной гранищы редколесий составил 0,74 м/год, горизонтальное продвижение сплошной гранищы редколесий - 0,20 м/год. На основе изучения возрастной структуры J. sibirica установлен факт его продвижения выще в горы в течение последних двух столетий. Изучен флористический состав горно-тундровых сообществ с разной долей участия J. sibirica. Коэффиииенты сходства видового состава сосудистых растений горных тундр (0,53-0,88) свидетельствуют об их типологическом сходстве. Вселение J. sibirica приводит к структурным перестройкам. Наблюдаемые тенденции для сообществ сосудистых растений не связаны с высотной приуроченностью. Состав лихеносинузий не зависит от доли участия J. sibirica в составе горно-тундровых сообществ, при этом демонстрирует зависимость от 
выссотыл над ур. м. В сообществвах нижней высотной группь видовое богатство лишайников и их обилие снижается.

Ключевые слова: разновременные аэро-, спутниковые и ландиафтные фотоснимки, верхняя граница древесно-кустарниковой растительности, еловые редколесья, Jипіреrus sibirica Burgsd., горно-тундровые растительные сообщества, изменение климата, Южный Урал.

\section{Введение}

Выявление и количественная оценка трансформации высокогорных экосистем одна из актуальнейших проблем экологии, роль которой значительно повышается на фоне современного изменения (потепления) климата.

Потепление климата обусловливает экспансию древесно-кустарниковой растительности в горные тундры и луга, а также увеличение густоты и продуктивности ранее произраставших древостоев.

Высокогорные экосистемы чутко реагируют на изменения условий среды и поэтому имеют индикаторное значение (Горчаковский, Шиятов, 1985). В последние десятилетия установлены многочисленные факты продвижения древесной и кустарниковой растительности выше в горы во многих регионах мира. Результаты таких исследований обобщены в работах Harsch et al. (2009) и Myers-Smith et al. (2011). В то же время в специальной литературе имеется ограниченное количество материалов по оценке экспансии кустарниковой растительности в горных регионах России. Работы такого рода единичны (Шиятов и др., 2014, 2014a; Моисеев и др., 2016).

Особый интерес в этой связи вызывают исследования нижних ярусов фитоценозов (травяно-кустарничкового и моховолишайникового) и изменений видового состава горных тундр, происходящих на фоне внедрения древесно-кустарниковой растительности.
Цель работы - выявление и оценка продвижения древесно-кустарниковой растительности выше в горы и влияния этого процесса на состав горно-тундровых сообществ с использованием комплекса методов.

\section{Материалы и методы}

Ключевой участок расположен в северозападной части Южного Урала на одной из горных вершин (г. Поперечная (N 5439' Е 58³9’), хр. Зигальга). Настоящими исследованиями были охвачены еловые редколесья и заросли Juniperus sibirica Burgsd., произрастающие в экотоне верхней границы древесной растительности (ЭВГДР), под которым понимается переходный пояс в горах между верхней границей распространения сомкнутых лесов и отдельных деревьев в тундре (Горчаковский, Шиятов, 1985).

Для количественной оценки крупномасштабных сдвигов верхних границ редколесий (растительных сообществ с сомкнутостью крон 0,2-0,3) был проведен сравнительный анализ аэрофотоснимков 1958 г. и спутникового изображения 2012 г., охватывающих район г. Поперечная (хр. Зигальга, Южный Урал). В геоинформационной системе ArcGIS 10.1. (ESRI Inc., США) данные дистанционного зондирования были совмещены с цифровой моделью рельефа разрешения $10 \times 10$ м, и закартированы пределы распространения редколесий в 1958 и 2012 гг. Оценка площади экспансии редколесий была получена с помощью модуля Spatial Statistics. Для расчета горизонтального продвижения границы редколесий 
использовалась функция оценки евклидового расстояния от линии, обрисовывающей границу редколесий в начале исследуемого периода, до линии современного распространения редколесий. Вертикальное продвижение границы редколесий оценивалось посредством определения медиан по значениям ячеек цифровой модели рельефа, находящихся на линиях, очерчивающих распространение редколесий в 1958 и 2012 гг. Наиболее благоприятные условия для экспансии редколесий в горную тундру определялись с использованием гистограмм, отображающих для растра, ограниченного областью сдвига границы редколесий, количество ячеек, которые относятся к различным классам по экспозиции, крутизне и степени каменистости.

Помимо этого при оценке изменений лесопокрытых площадей и площадей, занятых кустарниковой растительностью, был исполь- зован метод разновременных ландшафтных фотоснимков, сделанных с одних и тех же точек в разные годы (Шиятов, 2009). Для осуществления повторной съемки находилось точное место, с которого производилось фотографирование. В работе были использованы ландшафтные фотоснимки Л.Н. Тюлиной 1930 г., сделанные в районе г. Поперечная.

Для изучения возрастной структуры J. sibirica был заложен высотный профиль в ЭВГДР в пределах полосы его наибольшего распространения (рис. 1).

На профиле фиксировались две высотные группы: первая (I) - у верхней границы редко растущего $J$. sibirica (5-20\%); вторая (II) - у верхней границы распространения сомкнутых зарослей $J$. sibirica (> 40 \%). Вдоль склона были заложены пробные площади (ПП) размером 20х20 м; для высотной группы I было заложено 3 ПП, для высотной группы

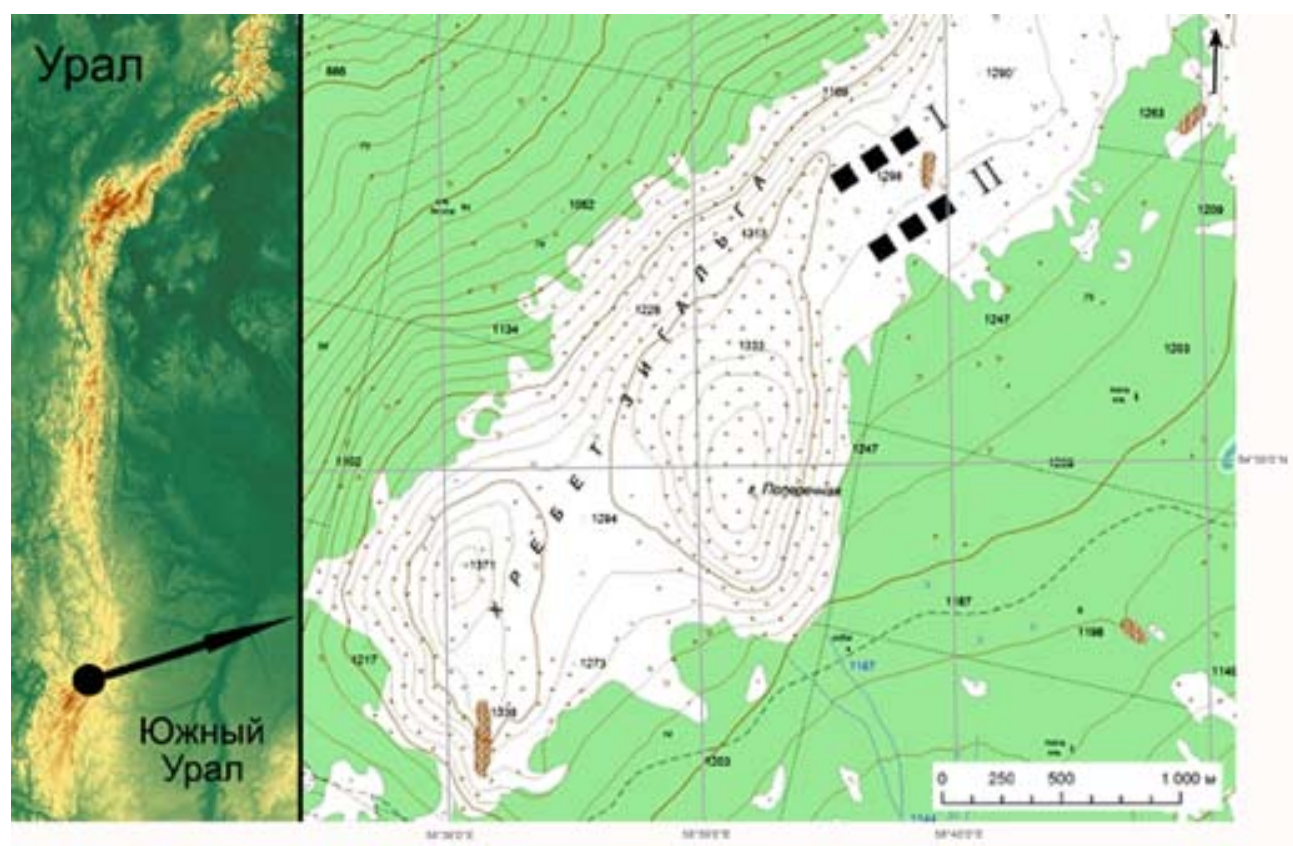

Рис. 1. Район исследования: хр. Зигальга, г. Поперечная; - - места закладки пробных площадей; I - верхняя высотная группа, II - нижняя высотная группа

Fig. 1. The research area: the Zigalga mountain range, Poperechnaya mountain; - - location of sampling units; I - the upper altitude group, II - the lower altitude group 
Таблица 1. Характеристика локальных условий местопроизрастания на заложенном высотном профиле

Table 1. Description of local conditions along high-altitude profile

\begin{tabular}{|c|c|c|c|c|c|c|}
\hline $\begin{array}{c}\text { Высотная } \\
\text { группа }\end{array}$ & $\begin{array}{c}\text { Высота } \\
\text { над } \\
\text { ур. м., м }\end{array}$ & $\begin{array}{c}\text { Положение } \\
\text { в рельефе }\end{array}$ & $\begin{array}{c}\text { Крутизна, } \\
\text { град. }\end{array}$ & $\begin{array}{c}\text { Степень } \\
\text { увлажнения } \\
\text { почвы }\end{array}$ & $\begin{array}{c}\text { Средняя высота } \\
\text { снежного } \\
\text { покрова, см }\end{array}$ & $\begin{array}{c}\text { Минимальная } \\
\text { температура } \\
\text { почвы, }{ }^{\circ} \mathrm{C}\end{array}$ \\
\hline I & 1290 & Перевал & $0-5$ & $\begin{array}{c}\text { Временно } \\
\text { сухие }\end{array}$ & $42,6 \pm 2,71$ & минус 4,5 \\
\hline II & 1260 & Ю-В & $5-10$ & Свежие & $61,5 \pm 1,31$ & минус 1,6 \\
\hline
\end{tabular}

II - 5 ПП. На каждой ПП на глубину 10 см в почву были заложены термологгеры и в зимнее время года произведено измерение высоты снежного покрова. Характеристика локальных условий местопроизрастания на профиле представлена в табл. 1.

На высотном профиле, заложенном в ЭВГДР г. Поперечная, по мере продвижения в гору степень увлажнения почвы изменяется от свежих до временно сухих почв (табл. 1). Данный профиль находится на склоне водораздельного хребта. Здесь в зимнее время года через перевал с запада перемещается большое количество снега, который в большей степени задерживается на более низких гипсометрических уровнях. Поэтому высота снежного покрова увеличивается со снижением высоты над ур. м. Почвы наиболее сильно промерзают в верхней группе - до минус $4,5^{\circ} \mathrm{C}$.

Оценка климатической обстановки в районе исследований производилась по данным инструментальных измерений метеостанции «Златоуст» (N 55¹0’22.42', Е 59³9'10.73’, высота над ур. м. 532 м), на которой имеются наиболее длительные ряды наблюдений для региона (с 1837 по 2014 г.). Метеостанция находится в 86 км от изучаемых объектов. Для анализа данных средней месячной температуры воздуха и суммарных месячных осадков за весь период метеонаблюдений были выбраны периоды теплого (с июня по август) и холодного (с ноября по март) времени года. Неоднородность временного ряда осадков была устранена путем введения переходных коэффициентов при смене дождемера на осадкомер (1952 г.) и исключения поправок на смачивание (1966 г.), опубликованных в специальном справочнике (Научно-прикладной справочник..., 1990). Аномалии средней температуры воздуха и суммарного количества осадков в холодном и теплом периодах каждого года определяли как разность между текущим значением и средним в базовом периоде (1960-1990 гг.).

На ПП у каждой особи J. sibirica фиксировалось точное местоположение, определялись высота, диаметр кроны в двух взаимно перпендикулярных направлениях и возраст, который устанавливали путем поиска места прикрепления плагиотропных ветвей к стволику с последующим спилом наиболее толстой ветви у стволика (рис. 2, Б-2, В-2).

Поправку к возрасту куста на высоту прикрепления ветви находили путем изучения хода роста у молодых особей J. sibirica от гипокотиля (рис. 2, А-1) стволика до места его разделения на плагиотропные ветви (рис. 2, A-2) в конкретных условиях. При невозможности нахождения данной точки, особенно у старых экземпляров, спил с ветви брали в ближайшем месте от прикрепления плагиотропных ветвей к стволику (рис. 2, В-3). Поправку к возрасту куста на вышеуказанную точку определяли путем изучения скорости роста плагиотропных ветвей в конкретных условиях с добавлением поправки на высоту 


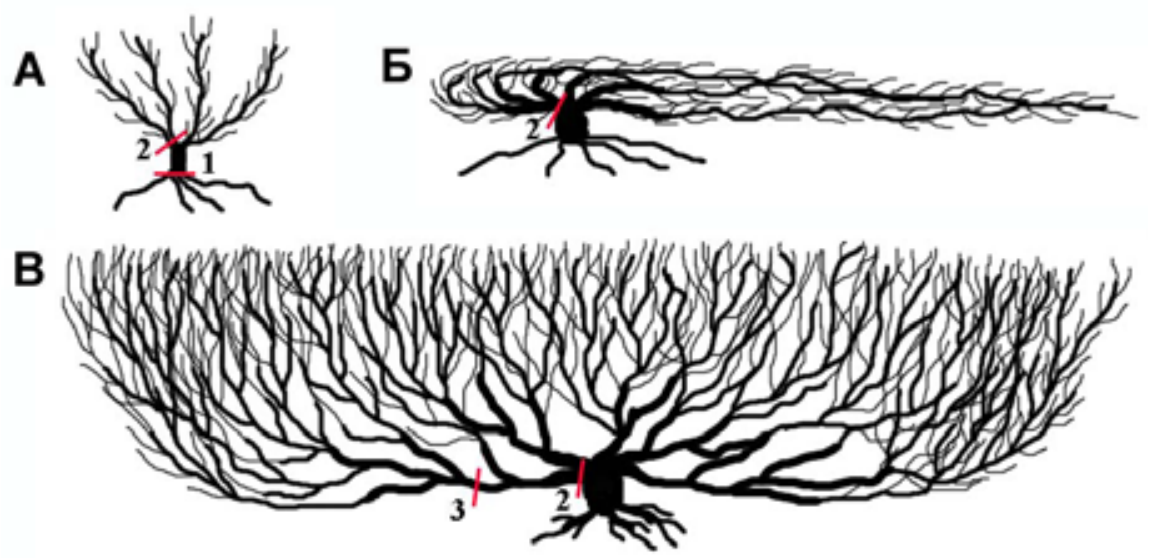

Рис. 2. Схема определения возраста у J. sibirica (рисунки А.А. Григорьева) у молодых (А) и взрослых (Б и В) особей: 1 - взятие спила у гипокотеля; 2 - в месте разделения стволика на плагиотропные ветви; 3 - в других местах на плагиотропной ветви

Fig. 2. J. Sibirica age determination scheme in young individuals (A) and adults (Б and B): 1 - at the hypocotil, 2 at the trunk plagiotropic branching, 3 - in other parts of the plagiotropic branch (illustrations by A. Grigoriev)

прикрепления ветви. Для абсолютной датировки времени появления или гибели кустарников, точного определения их возраста мы использовали методы древесно-кольцевого анализа. В основу этих методов положена процедура перекрестного датирования, которая позволяет выявлять ложные и выпадающие годичные кольца и привязывать индивидуальные древесно-кольцевые хронологии к календарной шкале (Шиятов и др., 2000). На

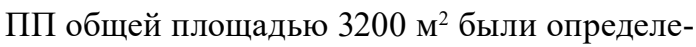
ны морфометрические показатели 211 кустов J. sibirica и для 114 установлен возраст.

Для сравнения морфометрических показателей кустов $J$. sibirica на двух высотных уровнях вся выборка была разделена по значению медианы на две возрастные группы: до 100 и более 100 лет. Проверка по критерию Колмогорова-Смирнова показала, что распределения показателей высоты кустов и диаметров крон в каждой возрастной группе для каждого высотного уровня расположения ПП не отличаются от нормального.

Для оценки изменения состава горнотундровых растительных сообществ были изучены лишайниково-травяные горные тундры с разным участием J. sibirica (от отсутствия до доминирования). При этом участки с доминированием $J$. sibirica не выбирались в его сплошных плотносомкнутых зарослях, а располагались так, что в границы учетной площадки $\left(100 \mathrm{~m}^{2}\right)$ мог попасть один или несколько крупных кустов. Все учетные площадки расположены на пологом склоне горы (3 градуса) юго-восточной экспозиции с каменистостью от 5 до $25 \%$, при этом с возрастанием высоты над ур. м. процент каменистости возрастает.

Сделано 18 геоботанических описаний (6 серий по 3 описания) с разным участием $J$ sibirica. Описания выполнены по стандартным геоботаническим методикам (Полевая геоботаника, 1964). На площадках учитывали видовой состав сосудистых растений с обилием, выраженным в баллах, а также давали общую характеристику с учетом высоты над ур. м., положения в рельефе, общего проективного покрытия, ярусности, разделения на подъярусы и их высоты. Для каждого описанного сообщества фиксировались GPS-координаты. 
Уточнение видовой принадлежности производилось с использованием Конспекта флоры Челябинской области (Куликов, 2005) и подтверждено в Музее ИЭРиЖ (Гербарий, SVER). Кроме этого, в пределах учетных площадей было сделано 47 описаний лишайниковых синузий. Для описания лишайниковых синузий использовали традиционные геоботанические методы, адаптированные в отношении лишайников (Магомедова, 2006). Описания выполняли на учетных площадках $0,0625 \mathrm{~m}^{2} \mathrm{c}$ использованием квадрат-сетки (25х25 cм).

Анализ сходства видового состава лишайниково-травяных горных тундр с разной долей участия $J$. sibirica проводили по методу Съеренсена-Чекановского (Шмидт, 1980). Изменения в структуре растительных сообществ выявляли с применением корреспондентного анализа (Correspondence Analysis / Анализ соответствий), используя балльные показатели обилия видов в программе BioDiversity Pro. Видовой состав сосудистых растений и лишайников в изученных растительных сообществах анализировали по отдельности.

\section{Результаты и обсуждение}

Анализ изменения растительного покрова с использованием дистанционных методов (аэрофото- и спутниковых изображений) в районе исследования на хр. Зигальга позволил выявить и оценить продвижение верхней границы редколесий за период с 1958 по 2012 гг. (рис. 3). Вертикальный сдвиг сплошной границы редколесий (без учета обособленных островков) по медиане составил 40 м

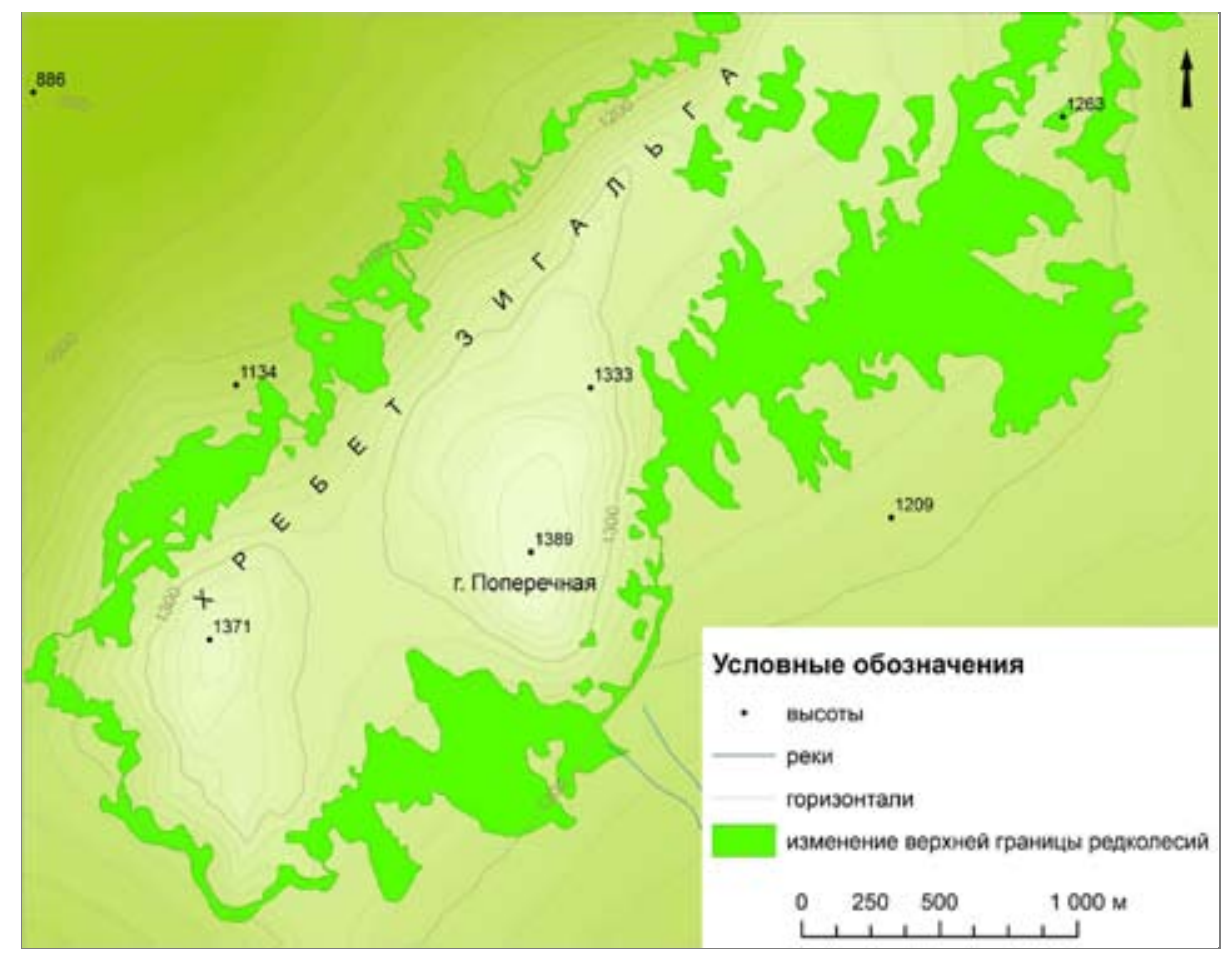

Рис. 3. Продвижение верхней границы редколесий в горную тундру в районе г. Поперечная (хр. Зигальга, Южный Урал) за период с 1958 по 2012 г.

Fig. 3. The upper limit shift of the open woodland area from 1958 to 2012 (Poperechnaya mountain, the Zigalga mountain range in the Southern Urals) 
(с 1223 до 1263 м) за исследуемый период, т. е. 0,74 м/год. Минимальное значение высоты расположения границы редколесий над ур. м. изменилось на 19 м (с 1075 до 1094 м), максимальное - на 14 м (с 1293 до 1307 м). Горизонтальное продвижение сплошной границы редколесий по медиане составило 11 м за период исследования $(0,20$ м/год), значения величины горизонтального сдвига лежат в диапазоне от 0 до 508 м.

Общая площадь продвижения границы редколесий равна 2,286 км².

Прослеживающиеся тенденции трансформации растительных сообществ на ис- следуемой территории свидетельствуют о наиболее существенной экспансии редколесий в тундру на юго-восточном склоне (рис. 4A), что объясняется не только более благоприятными климатическими условиями на этой части склона, но и большей пологостью и меньшей степенью каменистости. Важность последних двух факторов подтверждается анализом гистограмм, приведенных на рис. 4Б и 4В, который показал, что наибольшее продвижение границы редколесий происходило на пологих склонах (крутизной $0-5^{\circ}$ ) при наименьшей каменистости $(0-10 \%)$.

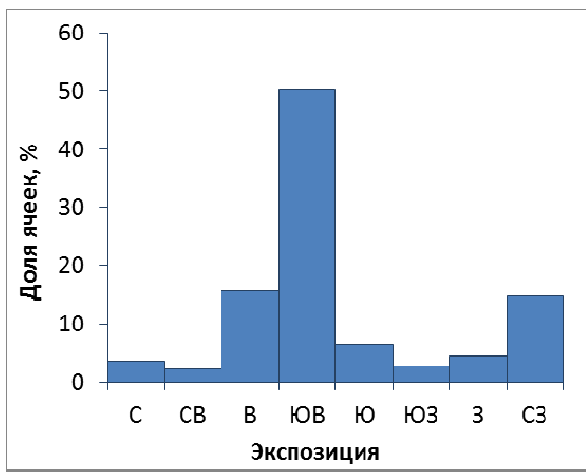

(A)

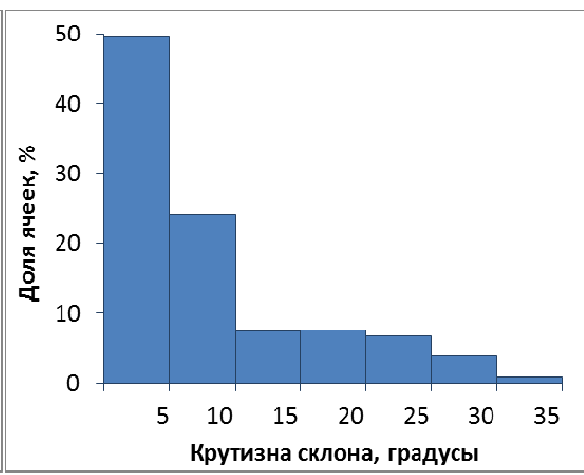

(Б)

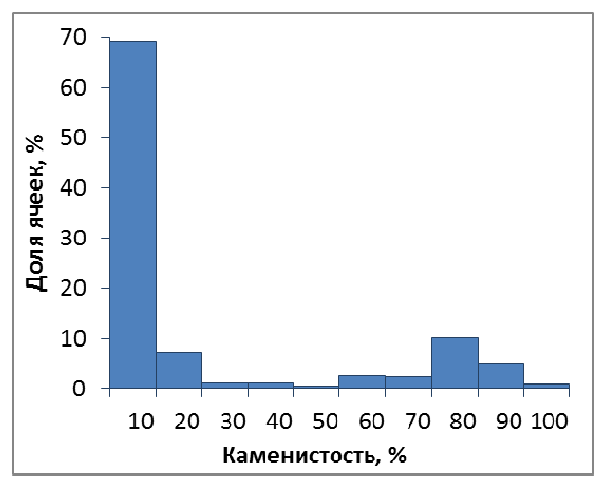

(B)

Рис. 4. Гистограмма распределения ячеек растра, принадлежащих области продвижения верхней границы редколесий в районе г. Поперечная (хр. Зигальга, Южный Урал) с 1958 по 2012 г., в зависимости от экспозиции (А), крутизны (Б) и каменистости (В) склона

Fig. 4. The distribution of the raster cells belonging to the area of the open woodland upper limit shift during 1958-2012, depending on the exposure (A), slope steepness (B) and stoniness (C) at Poperechnaya mountain, the Zigalga mountain range (the Southern Urals) 
Также изменения верхней границы еловые криволесья. Высота наиболее высоких древесно-кустарниковой растительности хорошо просматриваются на разновременных ландшафтных фотоизображениях (рис. 5 и 6). Анализ показывает, что 80 лет назад на нагорной террасе произрастали редкие ели стланиковой формы роста (рис. 5), высота которых не превышала 1-1,5 м. В настоящее время большую часть террасы занимают сомкнутые стволов достигает 5-6 м. Несколько выше, на каменистых участках склонов произрастают одиночные стланиковые ели.

В 1930 г. терраса была безлесой рис. 6. На переднем плане произрастали две еловые куртины, высота наиболее высоких стволиков составляла 3-3,5 м. К настоящему времени куртины разрослись, появились молодые
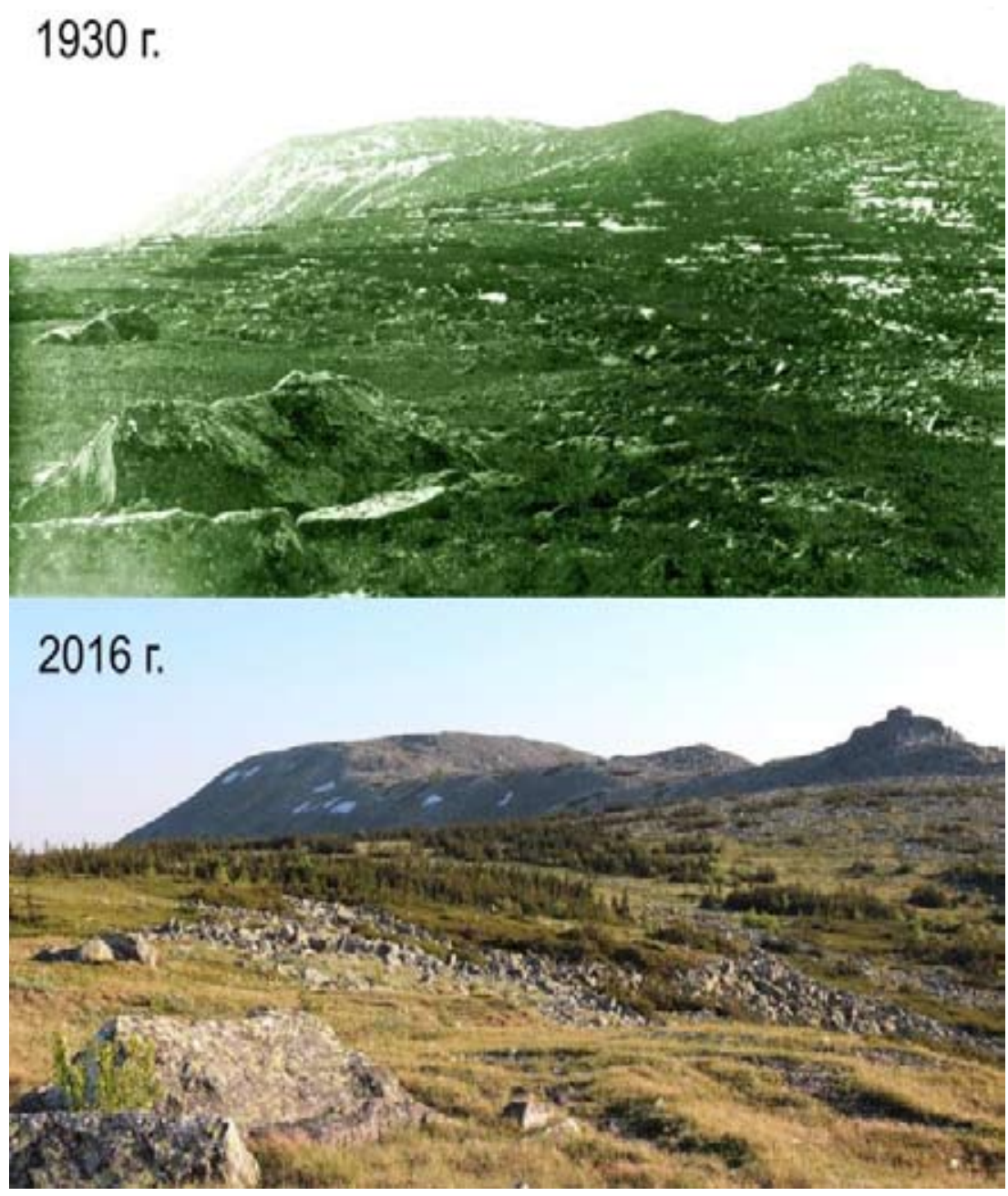

Рис. 5. Вид на водораздельную платообразную седловину и северо-восточный крутой сильнокаменистый склон г. Поперечная с центральной части северного водораздельного плато хр. Зигальга (N 5439.920', Е $058^{\circ} 39.970$ ', 1287 м). Снимок 1930 г. сделан Л.Н. Тюлиной, 2016 г. - А.А. Григорьевым

Fig. 5. View of the watershed plateau-like saddle and the northeastern steep and stony slope of Poperechnaya mountain from the central part of the northern watershed plateau of the Zygalga mountain range ( $5^{\circ} 4^{\circ} 39.920^{\prime}$, E $058^{\circ} 39.970^{\prime}$, the absolute altitude 1287 meters). 1930 - the photo by L.N. Tyulina, 2016 - the photo by A.A. Grigoriev. 


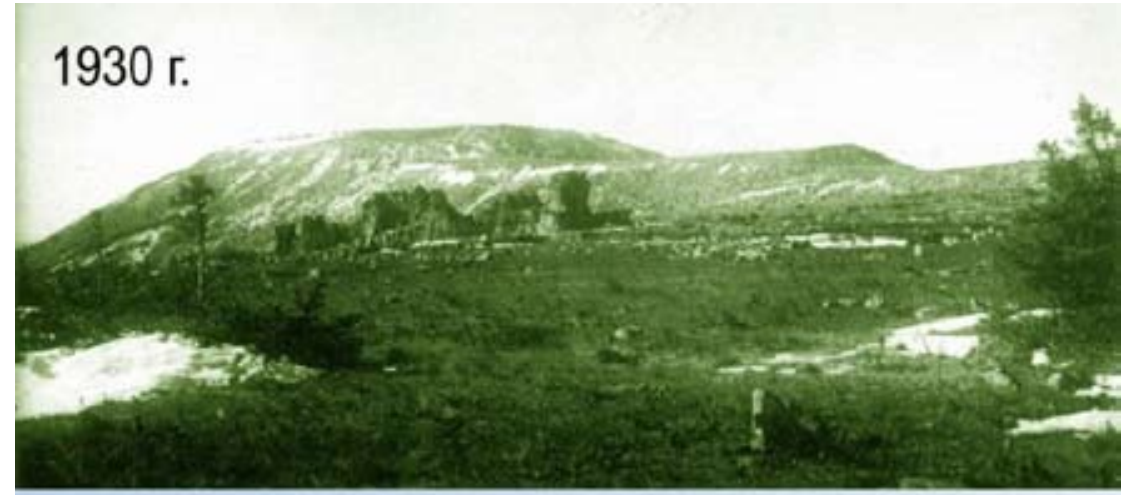

\section{6 r.}

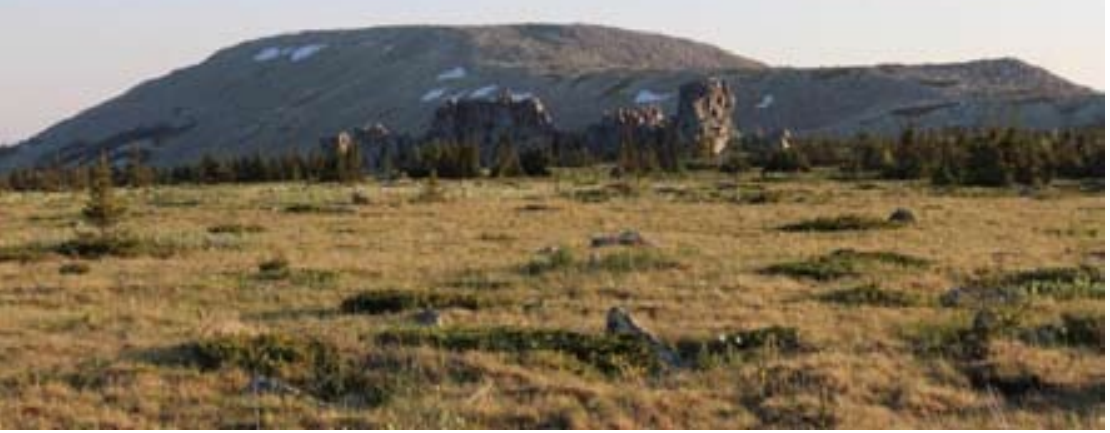

Рис. 6. Вид на «каменный город» и северо-восточный склон г. Поперечная с северного водораздельного плато хр. Зигальга (N 54³9.824', Е 058²40.164', 1292 м). Снимок 1930 г. сделан Л.Н. Тюлиной, 2016 г. А.А. Григорьевым

Fig. 6. View of the "stone city" and Poperechnaya mountain northeastern slope from the northern watershed plateau of the Zygalga mountain range (N 54³9.824', E 05840.164', the absolute altitude 1292 мeters). 1930 - the photo by L.N. Tyulina, 2016 - the photo by A.A. Grigoriev

ели одноствольной формы роста. Высота некоторых стволов достигает 7-8 м, а диаметр 16-18 см. С подветренной стороны полосы появилось несколько молодых елей высотой 0,8-1,4 м. В целом, на видимом участке склона произошло продвижение верхней границы древесной растительности выше в горы и, как следствие, сокращение площадей, занятых растительными сообществами горных тундр.

Анализ разновременных ландшафтных фотоснимков показал, что с 1930 по 2016 г. на хр. Зигальга произошло заметное продвижение древесной растительности выше в горы.

Однако дистанционные методы не позволяют оценить экспансию кустарниковой растительности, в частности наиболее распространенного вида - J. sibirica, из-за невозможности его объективной идентификации на снимках прошлых лет. Поэтому для оценки продвижения в горы кустарниковой растительности были проведены полевые исследования основных морфометрических показателей кустов, а также оценка изменения состава горно-тундровых сообществ при вселении J. sibirica.

Установлено, что по мере продвижения в гору (по мере ухудшения условий для роста растений) закономерно уменьшаются основные морфометрические показатели кустов J. sibirica (табл. 2). Так, средняя высота ку- 
Таблица 2. Средние ( \pm стандартное отклонение) показатели кустов J. sibirica на исследуемом профиле

Table 2. Mean value ( \pm standard deviation) of the $J$. sibirica shrubs parameters along high-altitude profile

\begin{tabular}{|c|c|c|c|c|c|c|c|}
\hline \multirow{3}{*}{$\begin{array}{l}\text { Высотная } \\
\text { группа }\end{array}$} & \multicolumn{5}{|c|}{ Морфометрические показатели кустов } & \multicolumn{2}{|c|}{$\begin{array}{c}\text { Площадные } \\
\text { характеристики }\end{array}$} \\
\hline & \multirow{2}{*}{$\begin{array}{l}\text { Возраст, } \\
\text { лет }\end{array}$} & \multicolumn{2}{|c|}{ Высота, см } & \multicolumn{2}{|c|}{ Диаметр кроны, см } & \multirow{2}{*}{$\begin{array}{c}\text { Густота, } \\
\text { шт/га }\end{array}$} & \multirow{2}{*}{$\begin{array}{c}\text { Сумма } \\
\text { проекций } \\
\text { крон, } \text { м²/га }^{2}\end{array}$} \\
\hline & & $\begin{array}{l}\text { возраст } \\
<100 \text { лет }\end{array}$ & $\begin{array}{l}\text { возраст } \\
\geq 100 \text { лет }\end{array}$ & $\begin{array}{l}\text { возраст } \\
<100 \text { лет }\end{array}$ & $\begin{array}{c}\text { возраст } \\
\geq 100 \text { лет }\end{array}$ & & \\
\hline I & $76 \pm 4,9$ & $21 \pm 1,4$ & $25 \pm 2,8$ & $179 \pm 13,8$ & $294 \pm 58,3$ & 533 & 1521 \\
\hline II & $130 \pm 6,6$ & $71 \pm 10,2$ & $101 \pm 5,8$ & $301 \pm 36,5$ & $454 \pm 43,4$ & 365 & 6060 \\
\hline
\end{tabular}

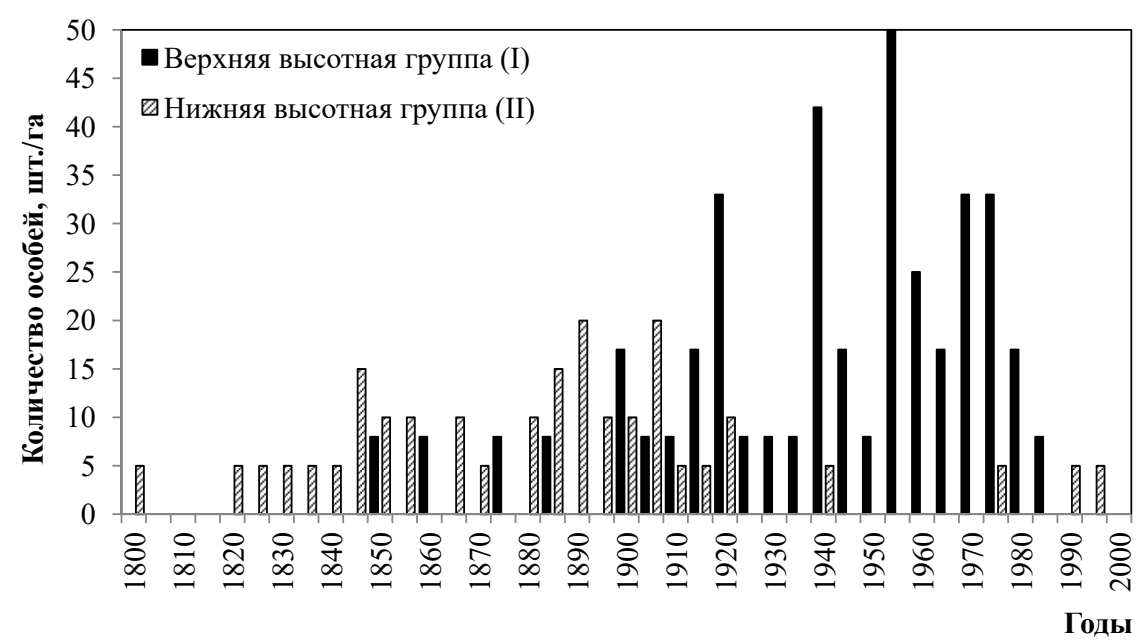

Рис 7. Заселение высотного профиля на северо-восточном склоне г. Поперечная (хр. Зигальга, Южный Урал) за последние два столетия. Высотные группы: I - верхняя (1290 м); II - нижняя (1260 м)

Fig. 7. Population of a high-altitude profile on the northeastern slope of Poperechnaya mountain (the Zigalga Range, the Southern Urals) for the past two centuries. High-altitude groups: I - upper (1290 m) and II - lower (1260 m)

стов уменьшается в 3,4 раза для возрастной группы до 100 лет и в 4,0 раза для группы более 100 лет, а диаметр крон - в 1,7 и 1,5 раза соответственно. Особого внимания заслуживают данные среднего возраста J. sibirica на профиле: в I группе он составляет 76 лет, во II - 130 лет. Площадные характеристики также различаются в зависимости от высоты над ур. м.: густота в 1,5 раза выше в верхней части профиля, а сумма проекций крон J. sibirica в 4 раза выше в нижней части профиля.

Изучение возрастной структурыJ. sibirica на заложенном высотном профиле показало, что в районе исследований помимо продвижения древесной растительности с середины XIX в. происходило продвижение выше в горы кустарниковой растительности.

В настоящих исследованиях значительный интерес представляет анализ периодов заселения J. sibirica изученного склона г. Поперечная на основе определения возраста отдельных особей, которые были объединены в 5-летние возрастные группы (рис. 7).

Данные рис. 7 свидетельствуют, что J. sibirica на г. Поперечная заселялся в разное время в зависимости от высоты над ур. м. Так, 
первые особи $J$ sibirica начали появляться в высотной группе II еще в начале XIX в. Этот процесс активизировался в XX в. Наиболее активно данный процесс происходил в конце XIX - начале XX в. В более экстремальных климатических условиях (в I высотной группе) первые кусты J. sibirica начали появляться в 1850-хх гг., а наиболее активным этот процесс был на всем протяжении XX в., особенно в периоды с 1900 по 1920 г. и наиболее массово после 1960-х гг. ХХ в.

Анализ данных инструментальных метеорологических наблюдений (рис. 8) свиде- тельствует, что климат в районе исследований стал более теплым и влажным. Наиболее существенное изменение в температурном режиме и режиме осадконакопления случилось в холодный период года. Так, временной ряд аномалий средней температуры воздуха в холодном периоде демонстрирует возрастание по линейному тренду на $1,7^{\circ} \mathrm{C}$ за 100 лет, для суммарных осадков увеличение составляет 48,8 мм за 100 лет. Достоверной тенденции по линейному тренду изменения аномалий данных климатических показателей в теплом периоде года не выявлено.

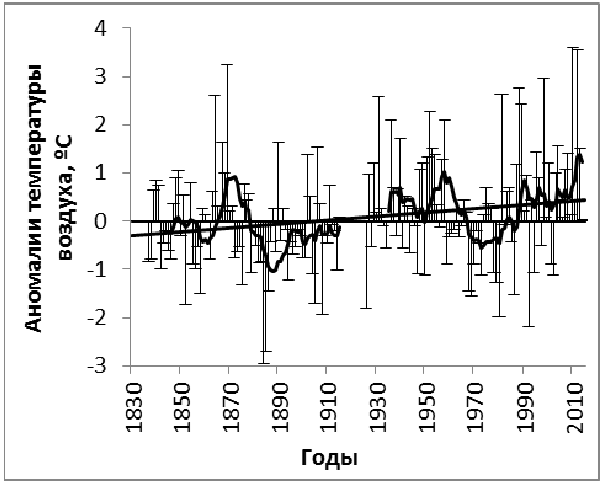

(A)

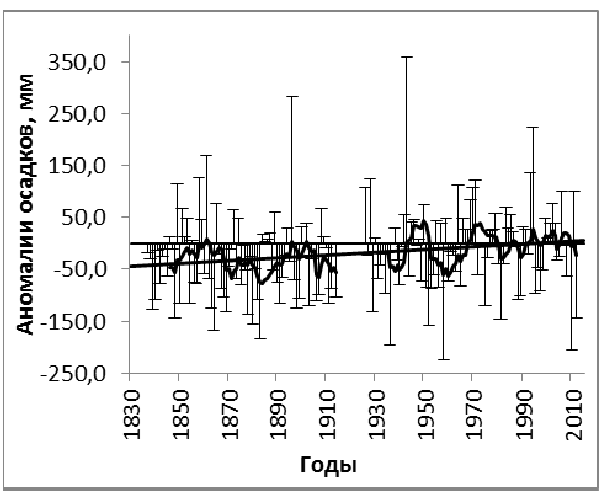

(B)

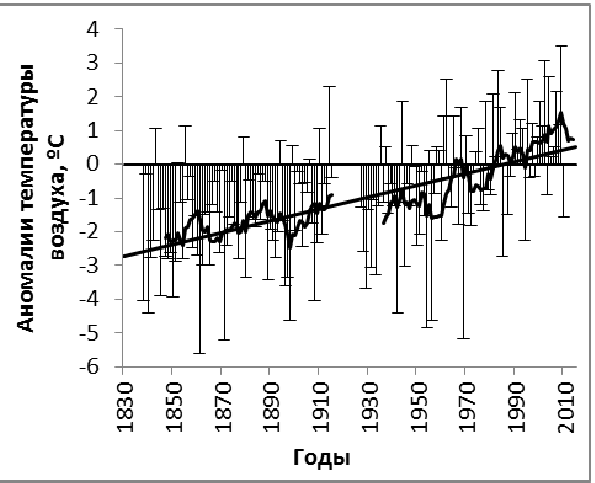

(Б)

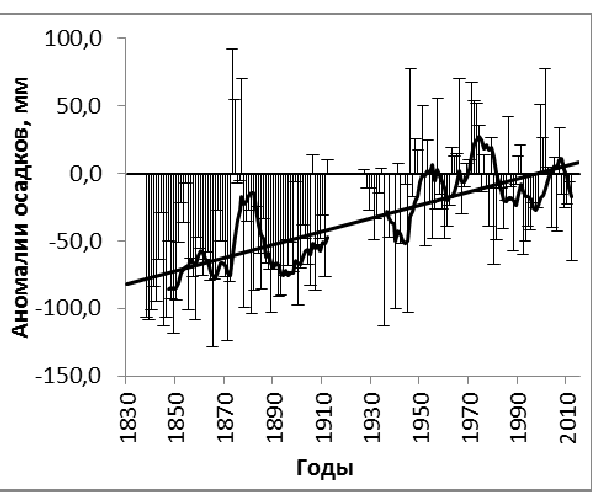

(Г)

Рис. 8. Временные ряды аномалий средней температуры воздуха у поверхности земли и сумм осадков в теплом (июнь-август; А, В) и холодном (ноябрь-март; Б, Г) периодах года для метеостанции «Златоуст» с 1837 по 2014 г. За норму принят период 1961-1990 гг. Жирной линией показано скользящее среднее с десятилетним периодом сглаживания

Fig. 8. Time series of anomalies of the average air temperature and total precipitation for warm (June-August; A, B) and cold (November-March; Б, Г) periods of the year, the weather station Zlatoust, 1837-2014. The period 1961-1990 is taken as standard. The bold curves show the moving average with a ten-year period of smoothing 
Заселению и последующему выживанию $J$ sibirica в самых экстремальных условиях на перевалах гор (І высотная группа) способствовало общее улучшение климатических условий в районе исследований, особенно увеличение количества осадков. На открытых участках J. sibirica подвергается снежной абразии и морозному иссушению, а аккумуляция снежных масс на склоне обеспечивает его выживание в условиях высокогорий в зимнее время года (рис. 9). Появление отдельных деревьев в тундре также благоприятствует задержанию снежных масс на склоне и меньшему промерзанию почв (Моисеев, 2011; Hagedorn et al., 2014). Все это способствует продвижению J. sibirica выше в горы.

Эти данные обусловили проведение геоботанических работ по изучению со- става горных тундр с разной долей участия J. sibirica.

Согласно типизации горных тундр Урала К.Н. Игошиной (1964) и П.Л. Горчаковского (1975), на изученной нами территории распространены растительные сообщества из формации лишайниковых тундр. Однако синузии лишайников в настоящее время занимают подчиненное положение в составе сообществ, их проективное покрытие не превышает $20 \%$. Мохообразные не имеют ценотического значения; их участие в составе сообществ пренебрежимо мало. Сосудистые растения преобладают в составе горных тундр исследованной территории. Эти данные позволяют нам отнести изученные горно-тундровые растительные сообщества к лишайниковотравяным.

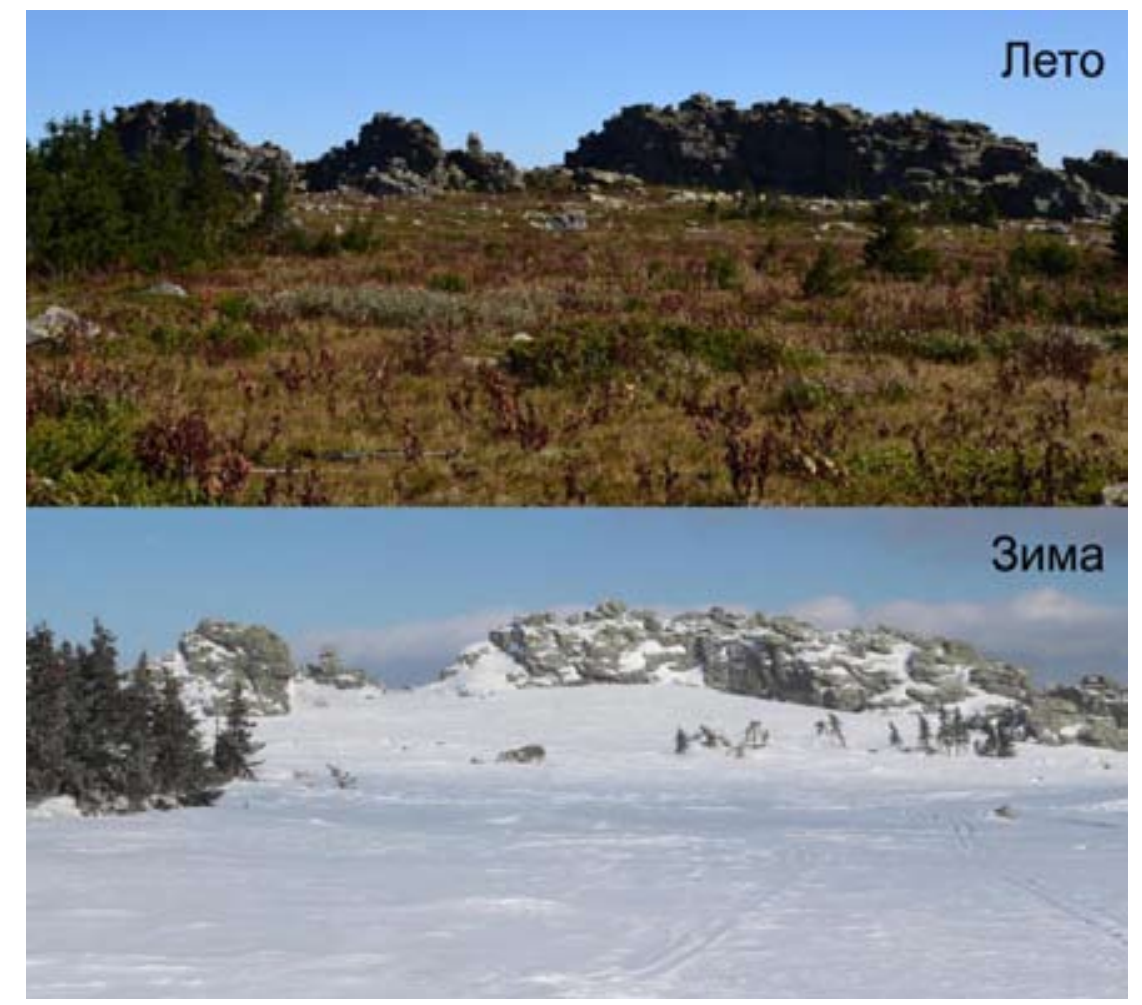

Рис. 9. Разносезонные ландшафтные снимки, сделанные в районе произрастания высотной группы I на г. Поперечная

Fig. 9. Seasonal landscape pictures of the growth area for altitude group I on the Poperechnaya mountain 
Лишайниково-травяные горные тундры без участия J. sibirica (Группа А). В этих сообществах доминировали в верхних частях пологого склона Lusula sibirica V. Krecz. и Festuca igoschinii Tzvel., ниже по склону Poa alpigena (Blytt) Lindm. и Aconogonon alpinum (All.). Видовая насыщенность - от 3 до 5 видов на учетную площадку $\left(0,625 \mathrm{~m}^{2}\right)$, а видовое богатство изменялось от 7 до 19 видов. Видовое богатство макролишайников в сообществах с их присутствием изменялось от 3 до 14 видов. В сообществах доминировали кустисто-разветвленные (Cladonia arbuscula (Wallr.) Flot, Cladonia rangiferina (L.) F.H. Wigg, Cladonia stellaris (Opiz) Pouzar \& Vězda, Cladonia stygia (Fr.) Ruoss), также довольно обильны шиловидные (Cladonia amaurocraea (Flörke) Schaer.) лишайники. Высота яруса 7-11 см.

Лишайниково-травяные горные тундры с незначительным (30-40 \% от общей площади) участием J. sibirica (Группа Б). В этих сообществах доминирует в верхних частях пологого склона $F$. igoschinii, ниже по склону - A. alpinum, Anemone biarmiensis (Juz.) Holub и Veratrum lobelianum Bernh. Видовая насыщенность - от 2 до 5 видов на учетную площадку, а видовое богатство изменялось от 7 до 19 видов. Видовое богатство макролишайников в сообществах, где они присутствуют, 7-12 видов. В сообществах доминируют кустисто-разветвленные (C. arbuscula, C. rangiferina, C. stellaris, C. stygia, Cladonia. uncialis (L.) F.H. Wigg.), кустисто-лопастные (Cetraria laevigata Rass., Flavocetraria cuculata (Bellardi) Kärnefelt et A. Thell) или кубковидные (Cladonia pleurota (Florke) Schaerer) лишайники. Высота яруса 7-9 см.

Кустарниково - ли ш й никовотравяные горные тундры с доминированием (85-95 \% от общей площади) J. sibirica (Группа В). На этих участках доминировали в верхних частях пологого склона Hieracium iremelense (Elfstr.) Juxip, F. igoschinii и L. sibirica; в нижних частях пологого склона затруднительно выделить доминанты в связи с малым покрытием сосудистых растений (5-7 \%) и большим проективным покрытием J. sibirica. Сосудистые растения представлены единичными экземплярами. Видовое богатство изменялось от 11 до 20 видов. Видовое богатство макролишайников в сообществах, где они присутствуют, 7-11 видов. В сообществах доминировали кустисто-разветвленные (C. arbuscula, C. rangiferina, C. stellaris, C. stygia, C. uncialis) или шиловидные (C. amaurocraea, Cladoniamacroceras (Delise) Hav., Cladonia subfurcata (Nyl.) Arnold) лишайники. Высота яруса 8,5-10 см.

В табл. 3 приведена общая характеристика изученных горно-тундровых сообществ.

Для определения сходства / различия видового состава изученных сообществ был проведен анализ по методу СъеренсенаЧекановского. Результаты анализа сходства видового состава изученных растительных сообществ показывают достаточно высокое флористическое единство (табл. 4). Близкие значения коэффициентов СъеренсенаЧекановского подчеркивают типологическое родство всех изученных сообществ и принадлежность их к одному типу горных тундр (лишайниково-травяным), независимо от доли участия J. sibirica и высотной группы. Во всех описанных вариантах горнотундровых сообществ лишайники сплошного покрова не формируют, развиваются моно- или поливидовыми куртинами. Однако в зарослях J. sibirica состав лишайников разнообразнее, эпигейные виды сочетаются с эпифитными (на ветвях J. sibirica и фрагментах отмершей древесины) и эпилитными видами на выходах камней (табл. 4). 
Таблица 3. Общая характеристика горных тундр (г. Поперечная, хр. Зигальга)

Table 3. Characteristics of mountain tundra (mountain Poperechnaya, the Zigalga mountain range)

\begin{tabular}{|c|c|c|c|c|}
\hline $\begin{array}{c}\text { Высотная группа } \\
\text { описаний }\end{array}$ & $\begin{array}{c}\text { Выходы камней, \% } \\
\text { от площади }\end{array}$ & $\begin{array}{l}\text { Проективное } \\
\text { покрытие } \\
\text { J. sibirica, \% }\end{array}$ & $\begin{array}{c}\text { Проективное } \\
\text { покрытие тр.-куст. } \\
\text { яруса, \% }\end{array}$ & $\begin{array}{c}\text { Проективное } \\
\text { покрытие мох.- } \\
\text { лиш. яруса, \% }\end{array}$ \\
\hline \multicolumn{5}{|c|}{ Лишайниково-травяные тундры с участием J. sibirica < 1 \% (группа А) } \\
\hline \multirow{3}{*}{ I (1290 м над ур. м.) } & 5 & 0 & 80 & 0 \\
\hline & 2 & 0 & 80 & 5 \\
\hline & 2 & $<1$ & 80 & 5 \\
\hline \multirow{3}{*}{ II (1260 м над ур. м.) } & 10 & 0 & 70 & 15 \\
\hline & 25 & $<1$ & 80 & 20 \\
\hline & 10 & 0 & 70 & 12 \\
\hline \multicolumn{5}{|c|}{ Лишайниково-травяные тундры с участием J. sibirica 30-40 \% (группа Б) } \\
\hline \multirow{3}{*}{ I (1290 м над ур. м.) } & 3 & 30 & 80 & 0 \\
\hline & 2 & 30 & 70 & 0 \\
\hline & 2 & 40 & 60 & 7 \\
\hline \multirow{3}{*}{ II (1260 м над ур. м.) } & 10 & 30 & 70 & 15 \\
\hline & 25 & 40 & 70 & 10 \\
\hline & 10 & 30 & 80 & 15 \\
\hline \multicolumn{5}{|c|}{ Кустарниково-лишайниково-травяные тундры (группа В) } \\
\hline \multirow{3}{*}{ I (1290 м над ур. м.) } & 5 & 95 & 7 & 0 \\
\hline & 2 & 95 & 5 & 7 \\
\hline & 2 & 85 & 5 & 5 \\
\hline \multirow{3}{*}{ II (1260 м над ур. м.) } & 10 & 90 & 10 & 12 \\
\hline & 25 & 90 & 30 & 10 \\
\hline & 10 & 85 & 60 & 10 \\
\hline
\end{tabular}

Таблица 4. Показатели сходства флористического состава лишайниково-травяных тундр

Table 4. Indexes of similarity for floristic composition of lichen-grass tundra

\begin{tabular}{|c|c|c|c|c|c|c|c|}
\hline \multirow{2}{*}{\multicolumn{2}{|c|}{$\begin{array}{c}\text { Высотная группа / } \\
\text { проективное покрытие } \\
\text { J. sibirica, \% }\end{array}$}} & \multicolumn{3}{|c|}{ I (1290 м над ур. м.) } & \multicolumn{3}{|c|}{ II (1260 м над ур. м.) } \\
\hline & & \multirow{2}{*}{$\begin{array}{c}\begin{array}{c}\text { Группа A } \\
(0)\end{array} \\
18 / 6\end{array}$} & \multirow{2}{*}{$\begin{array}{c}\begin{array}{c}\text { Группа Б } \\
(30-40)\end{array} \\
0,70^{\wedge}\end{array}$} & \multirow{2}{*}{$\begin{array}{c}\begin{array}{c}\text { Группа В } \\
(85-95)\end{array} \\
0,67^{\wedge}\end{array}$} & \multirow{2}{*}{$\begin{array}{c}\begin{array}{c}\text { Группа A } \\
(0)\end{array} \\
0,35^{\wedge}\end{array}$} & \multirow{2}{*}{$\begin{array}{c}\begin{array}{c}\text { Группа Б } \\
(30-40)\end{array} \\
0,40^{\wedge}\end{array}$} & \multirow{2}{*}{$\begin{array}{c}\begin{array}{c}\text { Группа В } \\
(85-95)\end{array} \\
0,44^{\wedge}\end{array}$} \\
\hline \multirow{3}{*}{ 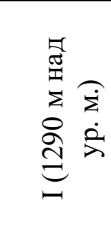 } & $\begin{array}{c}\text { Группа A } \\
(0)\end{array}$ & & & & & & \\
\hline & $\begin{array}{c}\text { Группа Б } \\
(30-40)\end{array}$ & $0,62 *$ & $19 / 7$ & $0,70^{\wedge}$ & $0,58^{\wedge}$ & $0,57^{\wedge}$ & $0,53^{\wedge}$ \\
\hline & $\begin{array}{c}\text { Группа В } \\
(85-95)\end{array}$ & $0,44 *$ & $0,42 *$ & $18 / 12$ & $0,69^{\wedge}$ & $0,77^{\wedge}$ & $0,83^{\wedge}$ \\
\hline \multirow{3}{*}{ 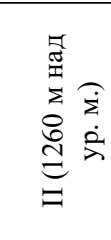 } & $\begin{array}{c}\text { Группа A } \\
(0)\end{array}$ & $0,63^{*}$ & $0,76^{*}$ & $0,73^{*}$ & $23 / 17$ & $0,88^{\wedge}$ & $0,78^{\wedge}$ \\
\hline & $\begin{array}{c}\text { Группа Б } \\
(30-40)\end{array}$ & $0,58^{*}$ & $0,72 *$ & $0,63^{*}$ & $0,90^{*}$ & $20 / 14$ & $0,74^{\wedge}$ \\
\hline & $\begin{array}{c}\text { Группа В } \\
(85-95)\end{array}$ & $0,67 *$ & $0,65^{*}$ & $0,83^{*}$ & $0,83^{*}$ & $0,92^{*}$ & $18 / 12$ \\
\hline
\end{tabular}

Примечание: в числителе - видовое богатство сосудистых растений, в знаменателе - видовое богатство лишайников. ^ - индекс Съеренсена-Чекановского для видового состава сосудистых растений, * - индекс Съеренсена-Чекановского для видового состава лишайников. 
Для уточнения изменений, происходящих в горно-тундровых растительных сообществах при вселении в них J. sibirica, был проведен корреспондентный анализ. Результаты его представлены на рис. 10 и 11.
На рис. 10 сообщества с доминированием J. sibirica сближены в нижней правой части графика, сообщества с отсутствием $J$ sibirica или его незначительным участием не показывают закономерного располо-

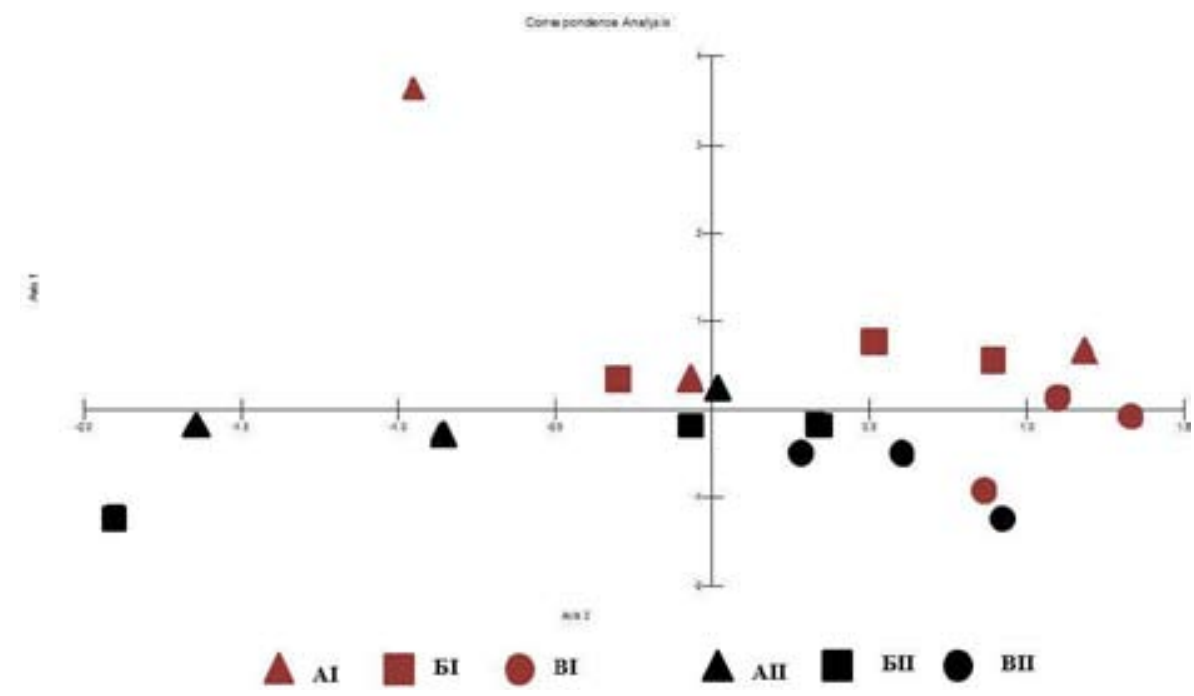

Рис. 10. Распределение растительных сообществ двух высотных групп с разной долей участия J. sibirica (сосудистые растения)

Fig. 10. Distribution of plant communities from two high-altitude groups with different $J$. sibirica cover (vascular plants)

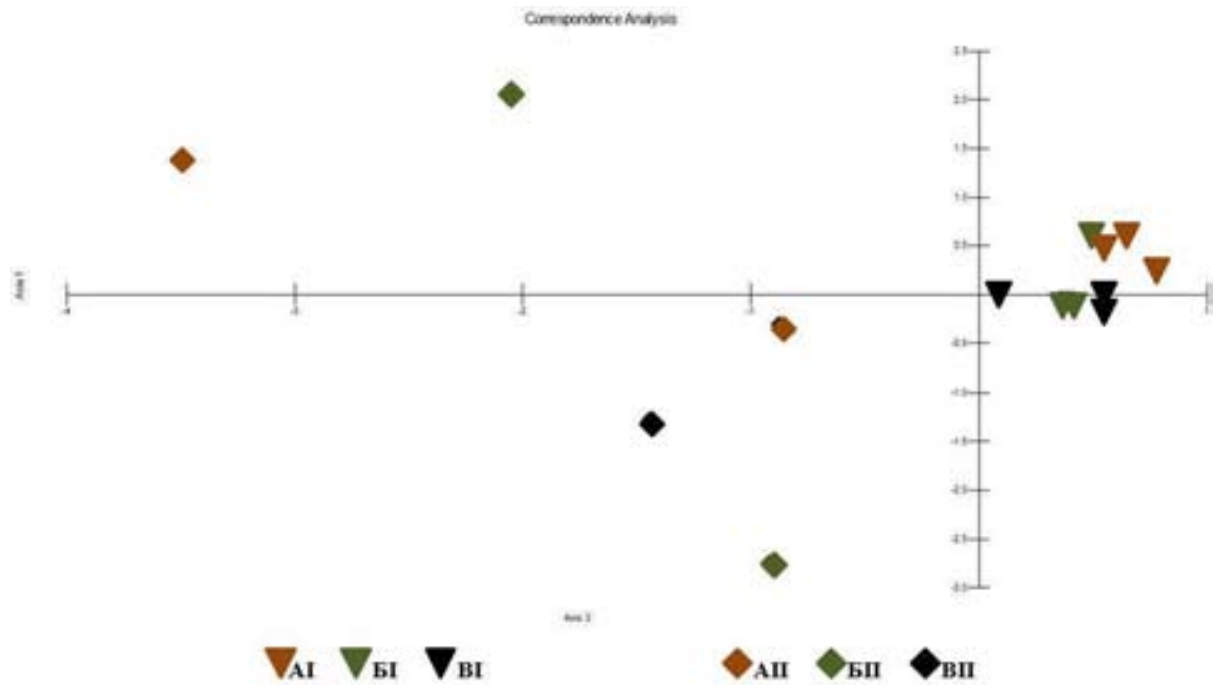

Рис. 11. Распределение лишайниковых синузий горно-тундровых сообществ двух высотных групп с разной долей участия J. Sibirica

Fig. 11. Distribution of lichensynusia mountain tundra communities from two high-altitude groups with different J. sibirica cover 
жения. Это распределение не зависит от принадлежности сообщества к высотной группе.

Распределение лишайниковых синузий (рис. 11) четко демонстрирует их приуроченность к двум высотным группам независимо от доли участия J. sibirica в структуре растительных сообществ.

\section{Заключение}

В XX в. отмечается наиболее активное продвижение верхней границы древеснокустарниковой растительности в горы. На хр. Зигальга с 1958 по 2012 г. помимо вертикального сдвига верхней сплошной границы редколесий отмечены горизонтальные изменения. Вертикальный сдвиг сплошной границы редколесий составил 0,74 м/год, горизонтальное продвижение сплошной границы редколесий - 0,20 м/год. Наиболее значительные изменения в распределении лесопокрытых площадей произошли на относительно пологих, лучше дренированных, с присутствием мелкозема и почвы участках склонов. Это подтверждается различиями в изображениях растительности на разновременных аэрофото-, спутниковых и ландшафтных снимках.
Поднятие верхней границы древесной растительности выше в горы случилось на фоне климатических изменений. В последнем столетии климат на Южном Урале стал более теплым и влажным. Наиболее существенные изменения в температурном режиме и режиме осадконакопления произошли в зимние месяцы.

Помимо еловых редколесий вверх в горы продвигаются кустарники, в частности J. sibirica, появление которого наблюдается в экстремальных условиях - на перевалах гор. Это подтверждается в изменениях возрастных, морфометрических и площадных характеристик кустов J. sibirica в зависимости от высоты его произрастания над ур. м.

Анализ флористического состава горных тундр свидетельствует об их типологическом сходстве и принадлежности к одному типу горных тундр. Однако вселение J. sibirica приводит к структурным перестройкам. Наблюдаемые тенденции для сообществ сосудистых растений не связаны с высотной приуроченностью.

Состав лихеносинузий не зависит от доли участия J. sibirica в составе горно-тундровых сообществ, при этом демонстрирует зависимость от высоты над ур. м.

Работа выполнена при финансовой поддержке проекта РФФИ 16-05-00454 и в рамках государственного задания Института экологии растений и жсивотных УрО РАН № 0400 2014-0024.

\section{Список литературы}

Горчаковский П.Л. (1975) Растительный мир высокогорий Урала. М., Наука, 284 с. [Gorchakovskij P.L. (1975) Flora of Ural highmountain. Moscow, Nauka, 284 p. (in Russian)]

Горчаковский П.Л., Шиятов С.Г. (1985) Фитоиндикация условий среды и природных процеессов в выссокогорьях. М., Наука, 208 с. [Gorchakovskij P.L., Shiyatov S.G. (1985) Phytoindication of environmental conditions and natural processes in highlands. Moscow, Nauka, 208 p. (in Russian)]

Игошина К.Н. (1964) Растительность Урала. Труды Ботанического института им. В.Л.Комарова АН СССР, Сер. 3, вып. 16: 83-230 [Igoshina K.N. (1964) Vegetation of Ural. Academic 
writings of Komarov Botanical Institute Academy of Science USSR, Ser. 3, Issue 16: 83-230 (in Russian)]

Куликов П.В. (2005) Конспект флоры Челябинской области (сосудистые растения). Екатеринбург, Миасс, Геотур, 537 с. [Kulikov P.V. (2005) Synopsis of Chelyabinsk region flora (vascular plants). Ekaterinburg, Miass, Geotur, 537 p. (in Russian)]

Магомедова М.А. (2006) Восстановление лишайникового покрова на гарях в предтундровых лесах Западной Сибири. Научный вестник Ямало-Ненеикого автономного округа. Биота Ямала и проблемы региональной экологии, 1(38): 27-38 [Magomedova M.A. (2006) Restoration of lichen cover on fireplaces in pretundra forests of West Siberia. Scientific bulletin of Yamalo-Nenets Autonomous Okrug. Biota of Yamal and problems of regional ecology, 1(38): 27-38 (in Russian)]

Моисеев П.А. (2011) Структура и динамика древесной растительности на верхнем пределе ее произрастания на Урале: автореф. дис. д-ра биол. наук. Екатеринбург, 44 с. [Moiseev P.A. (2011) Structure and dynamics of woody vegetation on the upper limit of its growth in the Urals: the author's abstract. dis. Dr. Biol. sciences. Ekaterinburg, 44 p. (in Russian)]

Моисеев П.А., Шиятов С.Г., Григорьев А.А. (2016) Климатогенная динамика древесной растительности на верхнем пределе ее распространения на хребте Большой Таганай за последнее столетие. Екатеринбург, УрО РАН, 136 с. [Moiseev P.A., Shiyatov S.G., Grigoriev A.A. (2016) Climatogenic dynamics of woody vegetation at the upper limit of its distribution on the Big Taganay ridge during the last century. Ekaterinburg, UB RAS, 136 p. (in Russian)]

Научно-прикладной справочник по климату СССР (1990) Серия 3. Вып. 9. Ленинград, Гидрометеоиздат, 557 с. [Scientific and applied handbook on climate of the USSR (1990) Series 3. Issue. 9. Leningrad, Gidrometeoizdat, 557 p. (in Russian)]

Полевая геоботаника: методическое руководство (1964) Том 3. М., Л., Изд-во АН СССР, 402 c. [Field geobotany: methodological guidance (1964) Vol. 3. Moscow, Leningrad, AS USSR, 402 p. (in Russian)]

Шиятов С.Г. (2009) Динамика древесной и кустарниковой растительности в горах Полярного Урала под влиянием современных изменений климата. Екатеринбург, УрО РАН, 216 с. [Shiyatov S.G. Dynamics of woody and shrub vegetation in Polar Ural mountains under influence modern climate changes. Ekaterinburg, UB RAS, 216 p. (in Russian)]

Шиятов С.Г., Ваганов Е.А., Кирдянов А.В., Круглов В.Б., Мазепа В.С., Наурзбаев М.М., Хантемиров Р.М. (2000) Методы дендрохронологии. Часть I. Основы дендрохронологии. Сбор и получение древесно-кольцевой информации. Красноярск, КрасГУ, 80 с. [Shiyatov S.G., Vaganov E.A., Kirdyanov A.V., Kruglov V.B., Mazepa V.S., Naurzbaev M.M., Hantemirov R.M. (2000) Methods of dendrochronology. Part I. Basics of dendrochronology. Collection and receiving tree-rings information. Krasnoyarsk, Krasnoyarsk State University, 80 p. (in Russian)]

Шиятов С.Г., Моисеев П.А., Григорьев А.А. (2014) Мониторинг климатогенной динамики высокогорной древесной растительности при помощи ландшафтных фотоснимков на Южном Урале. Исследования гор. Горные регионы Северной Евразии. Развитие в условиях глобальных изменений (Bопросы географии; сб. 137). В.М. Котляков (отв. ред.). М., Кодекс, с. 125155 [Shiyatov S.G., Moiseev P.A., Grigor'ev A.A. (2014) Monitoring of climatogenic dynamics of highmountain woody vegetation using landscape photos on Southern Ural. Research of mountain. 
Mountain regions of Northern Eurasia. Development in global changes conditions (Geographical questions; book 137). V.M. Kotlyakov (ed.). Moscow, Kodeks, p. 125-155 (in Russian)]

Шиятов С.Г., Моисеев П.А., Григорьев А.А. (2014а) Оценка современного состояния и динамики древесной растительности, произрастающей в высокогорьях Южного Урала, на основе использования разновременных ландшафтных фотоснимков. Труды Южно-Уральского государственного природного заповедника. Вып. 2. Л.Д. Петрова (отв. ред.) Уфа, Гилем, Башк. энцикл., с. 217-235 [Shiyatov S.G., Moiseev P.A., Grigor'ev A.A. (2014a) Evaluation of the current state and dynamics of woody vegetation growing in the high mountains of the Southern Urals, based on the use of time-lapse landscape photographs. Proceedings of the South Ural State Nature Reserve. Iss. 2. L.D. Petrova (ed.) Ufa, Gilem, Bashkir encyclopedia, p. 217-235 (in Russian)]

Шмидт В.М. (1980) Статистические методы в сравнительной флористике. Л., 176 с. [Shmidt V.M. (1980) Statistical methods in comparative floristics. Leningrad, 176 p. (in Russian)]

Hagedorn F., Shiyatov S.G., Mazepa V.S., Devi N.M., Grigor'ev A.A., Bartysh A.A., Fomin V.V., Kapralov D.S., Terent'ev M.M., Bugman H., Rigling A., Moiseev P.A. (2014) Treeline advances along the Urals mountain range - driven by improved winter conditions? Global Change Biology, 20(11): 3530-3543

Harsch M.A., Hulme P.E., McGlone M.S., Dunca R.P. (2009) Are treelines advancing? A global meta-analysis of treeline response to climate warming. Ecology Letters, 12(10): 1040-1049

Myers-Smith I.H., Forbes B.C., Wilmking M., Hallinger M., Lantz T., Blok D., Tape K.D., Macias-Fauria M., Sass-Klaassen U., Levesque E., Boudreau S., Ropars P., Hermanuts L., Trant A., Collier L.S., Weijers S., Rozema J., Rayback S.A., Schmidt N.M., Schaepman-Strub G., Wipf S., Rixen C., Menard C.B., Venn S., Goetz S., Andreu-Hayles L., Elmendorf S., Ravolainen V., Welker J., Grogan P., Epstein H.E., Hik1 D.S. (2011) Shrub expansion in tundra ecosystems: dynamics, impacts and research priorities. Environmental Research Letters, 6(4): 045509 